\title{
Toxic Effects of Copper, Cadmium, and Methoxychlor Shown by Neutral Red Retention Assay in Two Species of Freshwater Molluscs
}

\author{
Nikolett Molnar ${ }^{\#}$ and Peter P. Fong ${ }^{*}$
}

Department of Biology, Gettysburg College, Gettysburg, PA, 17325, USA

\begin{abstract}
We used neutral red retention assay in lysosomes of digestive gland cells as an indicator for stress effects by the environmental contaminants $\mathrm{Cu}, \mathrm{Cd}$, and the pesticide methoxychlor in two freshwater molluscs, the unionid mussel, Elliptio complanata (Lightfoot) and the ramshorn snail Helisoma trivolvis (Say). Mussels and snails were exposed for 7 and 14 days to $\mathrm{Cu}$ and $\mathrm{Cd}$ each at nominal concentrations of $2.5 \mu \mathrm{g} / \mathrm{L}, 5.0 \mu \mathrm{g} / \mathrm{L}$, and $10.0 \mu \mathrm{g} / \mathrm{L}$, and to methoxychlor concentrations of $1.0 \mu \mathrm{g} / \mathrm{L}, 10.0 \mu \mathrm{g} / \mathrm{L}$, and $100.0 \mu \mathrm{g} / \mathrm{L}$. Both mussels and snails exposed to $\mathrm{Cu}$ showed a significant increase in the percent of destabilized lysosomes compared with lab control and freshly-collected (field control) mussels at both 7 and 14 days exposure for all concentrations. Cd-exposed mussels did not show a significant difference with either of the controls at 7 days, but at 14 days exposure, Cd significantly increased the percent of destabilized lysosomes at all concentrations compared to field control mussels. Compared to laboratory controls, Cd increased lysosomal destabilization at $5.0 \mu \mathrm{g} / \mathrm{L}$ and $10.0 \mu \mathrm{g} / \mathrm{L}$. Snails exposed to $\mathrm{Cd}$ for 7 days had a significantly higher percentage of lysosomal destabilization than both lab and field controls but at 14 days, significant differences were only seen at the two highest $\mathrm{Cd}$ concentrations. Methoxychlor-exposed mussels showed no significant lysosomal destabilization at 7 days compared to controls. But at 14 days exposure, the pesticide increased the percentage of lysosomal destabilization at $10.0 \mu \mathrm{g} / \mathrm{L}$ compared to lab controls, and increased at both $10.0 \mu \mathrm{g} / \mathrm{L}$ and $100.0 \mu \mathrm{g} / \mathrm{L}$ compared to field control mussels. Methoxychlor-exposed snails had a higher percentage of lysosomal destabilization at 7 and 14 days at all concentrations compared to both controls with the exception of the $1.0 \mu \mathrm{g} / \mathrm{L}-7$ day exposure group. Snails were more sensitive to $\mathrm{Cd}$ and to methoxychlor than were mussels possibly because they lack an operculum and are thus completely exposed to the environment. The lowest observed effect concentration (LOEC) for Cd was $2.5 \mu \mathrm{g} / \mathrm{L}$ (14 days) for Elliptio and $2.5 \mu \mathrm{g} / \mathrm{L}$ (7 and 14 days) for Helisoma. For methoxychlor, the LOEC was $10.0 \mu \mathrm{g} / \mathrm{L}$ (14 days) for Elliptio and 10.0 and $1.0 \mu \mathrm{g} / \mathrm{L}$ (7 and 14 days, respectively) for Helisoma. The LOEC for $\mathrm{Cu}$ was $2.5 \mu \mathrm{g} / \mathrm{L}$ ( 7 and 14 day exposure) for both Elliptio and Helisoma. These results show that lysosomal destabilization as indicated by neutral red retention is a reliable indicator of stress from heavy metals and a pesticide in freshwater molluscs, including a taxon that is endangered or threatened in North America.
\end{abstract}

Keywords: Cadmium, copper, Elliptio, Helisoma, methoxychlor, lysosome, neutral red, toxicity.

\section{INTRODUCTION}

Heavy metals continue to be common pollutants in aquatic ecosystems and are toxic to aquatic organisms [1-4]. In particular, the detrimental effects of $\mathrm{Cu}$ and $\mathrm{Cd}$ have been documented in numerous studies [5-8]. Bivalve and gastropod mollusks are excellent sentinel organisms for the study of toxic effects of such metals in aquatic ecosystems [5, 9-12]. Because of their economic importance, marine bivalves have been particularly well studied and exposure to $\mathrm{Cu}$ and $\mathrm{Cd}$ has been shown to have detrimental effects on oysters [13, 14], mussels [15], and clams [16]. By contrast, relatively few studies have addressed the effects of the pesticide methoxychlor (2,2-bis(p-methoxyphenyl)-1,1,1trichloroethane) on molluscs (but see [17]), even though the pesticide has been used for decades and was detected in freshwater mussels (Lampsilis siliquoidea) at concentrations as high as $222 \mu \mathrm{g} / \mathrm{L}$ in the Red Cedar River, Michigan

*Address correspondence to this author at the Department of Biology, Gettysburg College, Gettysburg, PA, 17325, USA; Tel: 717 -337 -6154; Fax: 717-337-6157; E-mail: pfong@gettysburg.edu

"Present Address: Department of Pharmacology and Therapeutics, University of Florida College of Medicine, Cancer and Genetics Research Complex, Gainesville, Florida 32610, USA
[18]. Use of methoxychlor was banned in the United States in 2003, but continues to be used worldwide, particularly in developing countries $[19,20]$, with recent studies showing the potential of exposure to methoxychlor and other organochlorine pesticides as risk factors for Parkinson's Disease [21]. In the aquatic environment, pesticides have been shown to reduce species richness indices by reducing the abundance of zooplankton and predatory insects [22]. Some authors [23] argue that the highest priority for research in freshwater pollutant regulation and treatment be given to pesticides since they are common pollutants which pose human health hazards at environmental concentrations.

Neutral red retention assays in lysosomes have been used as a measure of stress in various organisms under different environmental conditions [13-16, 25-33]. Since lysosomes accumulate a diverse range of toxic chemicals that can eventually lead to cell injury through lysosomal damage [34, 35], destabilization of lysosomal membranes indicated by leakage of neutral red into the cytoplasm is a good indicator of stress. Lysosomal destabilization has been shown in oysters exposed to toxic algae [36] and to Fullerene C60 nanoparticles [24], in earthworms exposed to organophosphate pesticides [37], in clams carrying trematode parasites [38], in mussels exposed to alkylbenzene sulphonate [39], 
and to human pharmaceuticals [29, 30, 32, 33]. The vast majority of these and other studies have utilized marine invertebrates even though freshwater molluscs are excellent sentinel organisms under constant pollution pressure.

We used neutral red retention assay to assess the effects of $\mathrm{Cu}, \mathrm{Cd}$, and methoxychlor exposure on two common freshwater invertebrates with a broad geographic distribution in North America, the ramshorn snail Helisoma trivolvis and the unionid mussel Elliptio complanata. We chose to test $H$. trivolvis because it lives in slow moving or even stagnant streams where toxicant-bound sediments and organic materials would tend to settle, accumulate, and become food for snails. E. complanata was chosen because it lives within toxicant-containing sediments and filters large volumes of water containing potential toxicants. Another reason is because unionids are endangered and threatened in North America, thus knowledge of their sensitivity to aquatic toxicants will aid conservation efforts. Finally, since both $H$. trivolvis and E. complanata are commonly used freshwater molluscs in aquatic toxicology experiments [40, 41], comparisons with different pollutants can be made.

\section{MATERIALS AND METHODS}

\section{Animal Collection and Exposure to Toxicants}

Mussels, Elliptio complanata, and snails, Helisoma trivolvis were collected by hand from Marsh Creek, Adams County, Pennsylvania. Mussels (10 cm shell length) were collected in September and October, 2006. Snails (1.5-2.0 $\mathrm{cm}$ shell length) were collected in June and July, 2007. After collection, all animals were immediately transported (10 minutes) to the laboratory at Gettysburg College where they were allowed to acclimate in the test aquaria in the water from which they were collected. All animals were used within 24 hours of collection.

Animals were placed in 3-liter plastic aquaria (1 mussel or 1 snail per aquarium) supplied with air stones for aeration. The final aquarium volume was $3000 \mathrm{ml}$ for mussels and $1500 \mathrm{ml}$ for snails (since snails are considerably smaller). All experiments were carried out at room temperature (20-22 ${ }^{\circ} \mathrm{C}$ ). For mussel experiments, the control solution was dechlorinated tap water. For snail experiments, we found dechlorinated tap water to be unhealthy, so the control solution was creek water from the collecting site. Due to heavy parasitism by larval digenetic trematodes that was undetectable prior to toxicant exposure, some of the snails tested were unusable. We re-tested three groups of snails in July 2010 (14-day exposure to $\mathrm{CuSO}_{4} 5.0 \mu \mathrm{g} / \mathrm{L}$ and $\mathrm{CdCl}_{2} 2.5 \mu \mathrm{g} / \mathrm{L}$, and the 7-day control for methoxychlor). The 2007 and 2010 groups were then pooled since there was no statistically significant difference between groups.

Following acclimation, each aquarium received nominal concentrations of toxicants in order to establish the final concentrations of $0,2.5,5.0$, and $10.0 \mu \mathrm{g} / \mathrm{L}$ for both $\mathrm{Cu}$ (as $\left.\mathrm{CuSO}_{4}\right)$ and $\mathrm{Cd}\left(\mathrm{CdCl}_{2}\right)$, and $1.0,10.0$, and $100.0 \mu \mathrm{g} / \mathrm{L}$ for methoxychlor. These concentrations were selected because they are similar to environmental concentrations and have been used in previous toxicity studies on marine animals [13, 42]. All chemicals were purchased from Sigma Chemical Company. Both $\mathrm{CuSO}_{4}$ and $\mathrm{CdCl}_{2}$ were dissolved in either de-chlorinated tap water (for mussels) or creek water (for snails). Methoxychlor was dissolved in $100 \% \mathrm{ETOH}$ and diluted to a final concentration of no more than $0.1 \% \mathrm{ETOH}$. Both mussels and snails were exposed to toxicants for 7 and 14 days. All 14-day exposure groups received fresh solutions on day 8 . Mussels were fed every two days with powdered Chlorella algae; snails received Romaine lettuce ad libidum. After the 7 or 14 days exposure, animals were dissected, their digestive glands removed, and the cells processed for neutral red retention assays. We also collected animals fresh from the field and immediately dissected their digestive glands for neutral red retention assays as field controls.

\section{Neutral Red Retention-Lysosomal Destabilization Assay}

We slightly modified the methods from those of [13]. Shells of mussels and snails were crushed with a C-clamp and their digestive glands removed. A portion of the digestive gland $\left(<2 \mathrm{~mm}^{2}\right)$ was placed in a $1.5 \mathrm{ml} \mathrm{micro-}$ centrifuge tube containing $1.0 \mathrm{ml} \mathrm{Calcium} / \mathrm{Magnesium}$ Free Saline (CMFS: $1.19 \mathrm{~g} / \mathrm{L}$ HEPES, $6.43 \mathrm{~g} / \mathrm{L} \mathrm{NaCl}, 0.37 \mathrm{~g} / \mathrm{L}$ $\mathrm{KCl}, 1000 \mathrm{ml} \mathrm{DI} \mathrm{H}_{2} \mathrm{O}$ ). Digestive glands were homogenized with a small Teflon tissue homogenizer to break the tissue into individual cells. Trypsin, $0.4 \mathrm{mg}$, was added to the microcentrifuge tube and shaken by hand for 5 minutes. Neutral red dye solution was prepared fresh for each assay. The primary stock solution was prepared first by the addition of $4.0 \mathrm{mg}$ of neutral red to $1.0 \mathrm{ml}$ of DMSO. A total of $60 \mu \mathrm{L}$ of the primary stock solution was then added to $5.94 \mathrm{ml}$ of CMFS in a $50 \mathrm{ml}$ foil-covered beaker at room temperature. Three microscope slides were set up for each individual animal in each group. A total of $40 \mu \mathrm{L}$ of cell suspension was placed on each microscope slide and $40 \mu \mathrm{L}$ of neutral red was added to each cell suspension. Slides were covered with a cover slip and incubated in a humidified chamber at $23.5^{\circ} \mathrm{C}$ for 60 minutes.

After incubation, the slides were removed from the chamber and examined under a compound microscope at $400 x$. For each slide, the first fifty cells encountered were evaluated for destabilized lysosomes. Lysosomes that retained neutral red were scored as stable. Cells with neutral red that had leaked into the cytoplasm were scored as having destabilized lysosomal membranes. Ambiguous cells, ones with neutral red leakage into the cytoplasm along with some retained within lysosomes were not scored. The mean percent of cells with destabilized lysosomes was calculated for each animal and thereafter for each toxicant group. Mean differences between groups were analyzed using one-way ANOVA.

\section{RESULTS}

While control animals showed some destabilized lysosomes, there was no significant difference in mean percent destabilization between any control (lab controls $v s$. field controls) in either species (for Elliptio: one-way ANOVA, F $=1.25, \mathrm{p}=0.32$; for Helisoma: one-way ANOVA, $\mathrm{F}=1.43$, $\mathrm{p}=0.25)$.

For the mussel Elliptio complanata, exposure to $\mathrm{Cu}$ had a significant effect on the mean percentage of destabilized lysosomes for both the 7-day exposure (one-way ANOVA, F $=10.01, \mathrm{p}=0.0006)$ and the 14-day exposure $(\mathrm{F}=20.11, \mathrm{p}<$ 
0.0001 , Fig. 1). There were significant differences between all three $\mathrm{Cu}$ concentrations and both field control and lab controls at both 7 and 14 days (Fisher's PLSD, $0.0006-$ $0.0001)$.

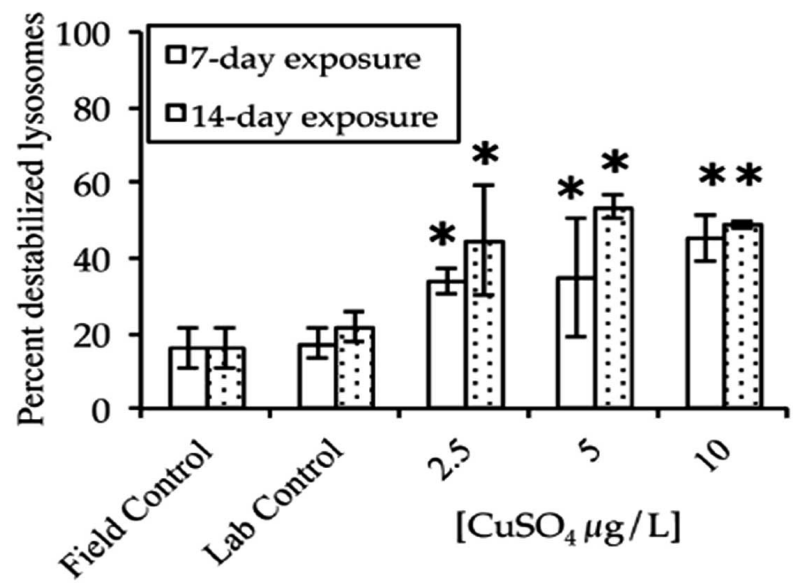

Fig. (1). Percent of destabilized lysosomes of digestive gland cells in Elliptio complanata exposed to three concentrations of $\mathrm{CuSO}_{4}$ for 7 (open bars) and 14 (stippled bars) days. Field control clams were tested immediately after collection. Sample sizes were $n=3$ per group. *: $\mathrm{P}<0.0003-0.0001$ vs. both field control and laboratory control.

Exposure to $\mathrm{Cd}$ also had a significant effect on the mean percentage of destabilized lysosomes, but only for the 14day exposure (one-way ANOVA, $\mathrm{F}=7.18, \mathrm{p}=0.0005$, Fig. 2). There were significant differences between the two highest $\mathrm{Cd}$ concentrations and both controls (Fisher's PLSD, $0.01-0.004)$. But, the $2.5 \mu \mathrm{g} / \mathrm{L}$ concentration was only significant when compared with the field control $(p=0.03)$.

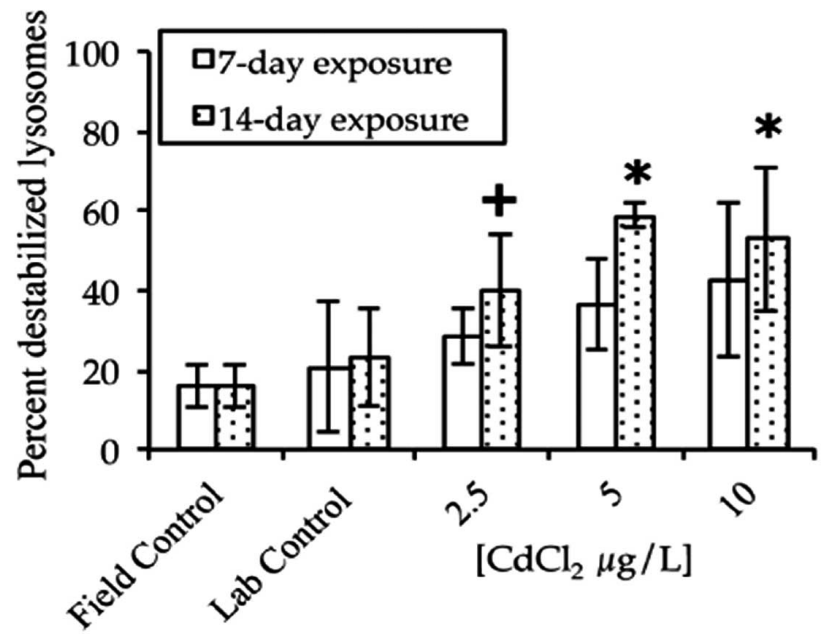

Fig. (2). Percent of destabilized lysosomes of digestive gland cells in Elliptio complanata exposed to three concentrations of $\mathrm{CdCl}_{2}$ for 7 and 14 days. Field control clams as in Fig. (1). Sample sizes were $\mathrm{n}=3$ per group. ${ }^{*}: \mathrm{P}<0.004-0.001 v s$. both field and laboratory controls; +: $\mathrm{P}<0.03$ vs. field control.

Exposure of mussels to methoxychlor had a significant effect on the mean percentage of destabilized lysosomes, and similar to the results for $\mathrm{Cd}$, the differences occurred only at the 14-day exposure time (one-way ANOVA, $\mathrm{F}=4.34, \mathrm{p}=$ 0.02 , Fig. 3). There were significant differences between the $10 \mu \mathrm{g} / \mathrm{L}$ group and both controls (Fisher's PLSD, $0.009-$
$0.004)$. The $100 \mu \mathrm{g} / \mathrm{L}$ group was significantly different only from the field control $(\mathrm{p}=0.004)$. Overall, for E. complanata, there was no dose response of toxicity for either exposure period for any of the three toxicants. In the case of the 14day exposure, the intermediate concentrations of all three toxicants were as toxic as the high concentrations.

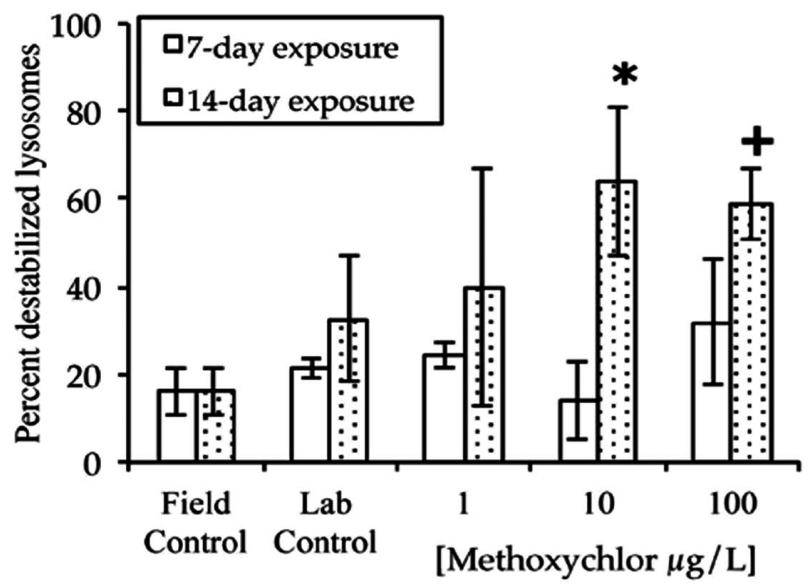

Fig. (3). Percent of destabilized lysosomes of digestive gland cells in Elliptio complanata exposed to three concentrations of methoxychlor for 7 and 14 days. Field control clams as in Fig. (1). Sample sizes were $\mathrm{n}=3$ per group. $*$ : $\mathrm{P}<0.004-0.009 v s$. both field and laboratory controls; +: $\mathrm{P}<0.004 v s$. field control.

For the snail Helisoma trivolvis, exposure to $\mathrm{Cu}$ had a significant effect on the mean percentage of destabilized lysosomes for both a 7-day exposure (one-way ANOVA, $\mathrm{F}=$ 45.39, $\mathrm{p}<0.0001)$ and 14-day exposure $(\mathrm{F}=23.85, \mathrm{p}<$ 0.0001 , Fig. 4). There were significant differences between all three $\mathrm{Cu}$ concentrations and both field control and lab control snails (Fisher's PLSD, $0.003-<0.0001$ ).

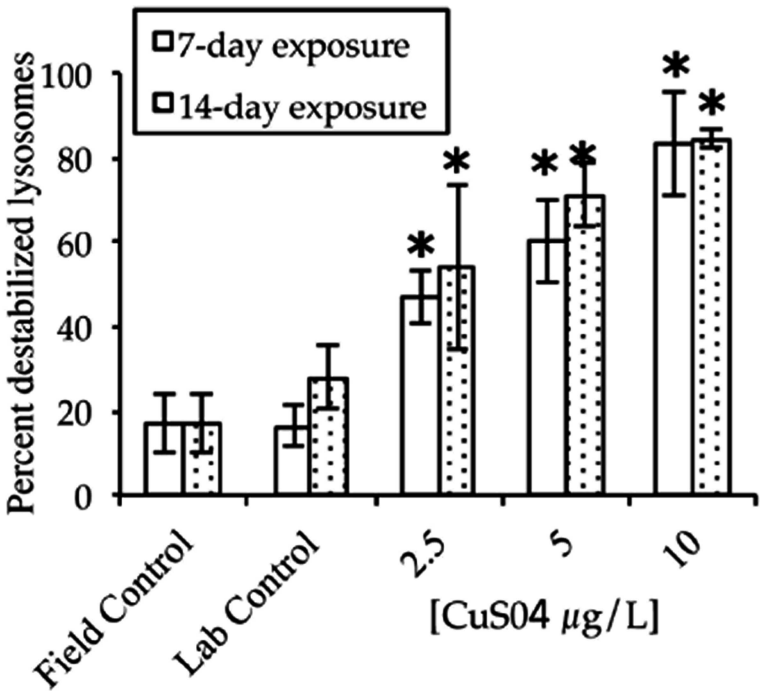

Fig. (4). Percent of destabilized lysosomes of digestive gland cells in Helisoma trivolvis exposed to three concentrations of $\mathrm{CuSO}_{4}$ for 7 and 14 days. Field control snails were tested immediately after collection. Sample sizes were $\mathrm{n}=4-5$ per group. $*$ : $\mathrm{P}<0.003$ $0.0001 \mathrm{vs}$. both field and laboratory controls.

Similarly, exposure to $\mathrm{Cd}$ had a significant effect on the mean percentage of destabilized lysosomes for both a 7-day exposure $(\mathrm{F}=20.63, \mathrm{p}<0.0001)$ and 14-day exposure $(\mathrm{F}=$ $7.72, p=0.003$, Fig. 5). There were significant differences 
between all three $\mathrm{Cd}$ concentrations and both field control and lab control snails (Fisher's PLSD, 0.03 - 0.0006).

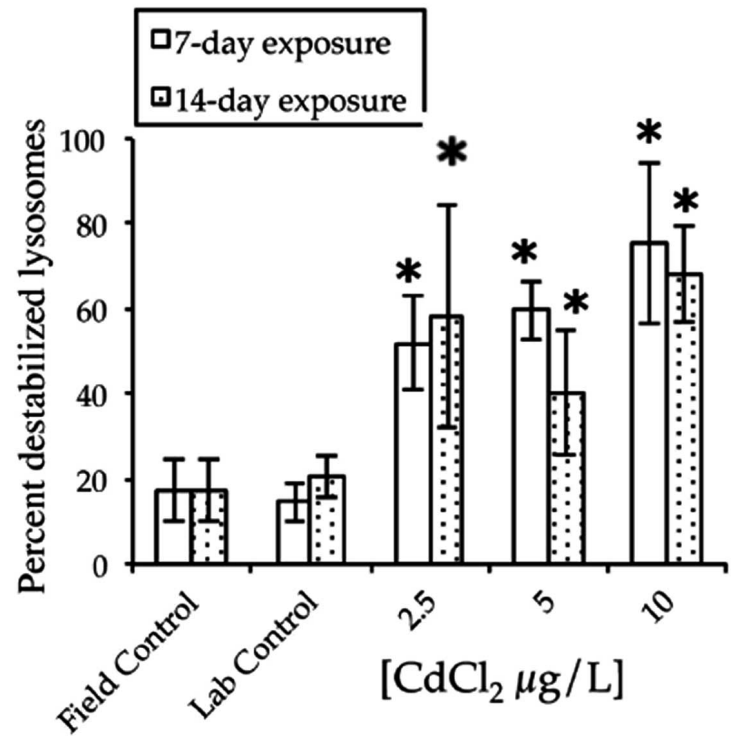

Fig. (5). Percent of destabilized lysosomes of digestive gland cells in Helisoma trivolvis exposed to three concentrations of $\mathrm{CdCl}_{2}$ for 7 and 14 days. Field control snails as in Fig. (4). Sample sizes were $\mathrm{n}=4-5$ per group. $*$ : $\mathrm{P}<0.03-0.0001 \mathrm{vs}$. both field and laboratory controls.

Exposure of snails to methoxychlor had a significant effect on the mean percentage of destabilized lysosomes for both the 7-day exposure $(\mathrm{F}=19.57, \mathrm{p}=0.0003)$ and the 14day exposure $(\mathrm{F}=108.66, \mathrm{p}<0.0001$, Fig. 6). Except for the $1 \mu \mathrm{g} / \mathrm{L}-7$-day exposure group $(\mathrm{p}=0.07)$, there were significant differences between the three methoxychlor concentrations and both field control and lab control snails (Fisher's PLSD, $0.002-0.0001)$. Overall, for $H$. trivolvis, there was a trend of increasing lysosomal destabilization with increasing $\mathrm{Cu}$ and methoxychlor concentrations, but this trend was not clear with $\mathrm{Cd}$.

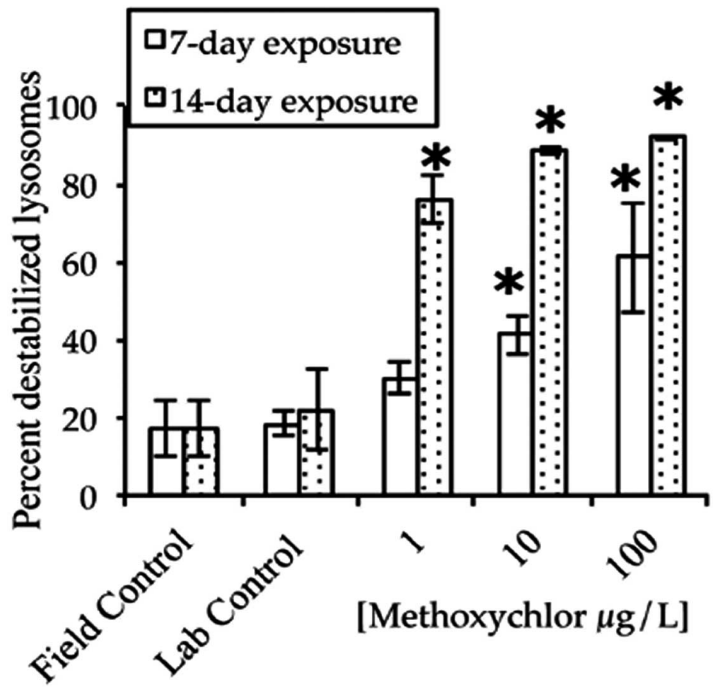

Fig. (6). Percent of destabilized lysosomes of digestive gland cells in Helisoma trivolvis exposed to three concentrations of methoxychlor for 7 and 14 days. Field control snails as in Fig. (4). Sample sizes were $\mathrm{n}=3-4$ per group. ${ }^{*}$ : $\mathrm{P}<0.02-0.0001$ vs. both field and laboratory controls.

\section{DISCUSSION AND CONCLUSION}

We found that the toxicants $\mathrm{Cu}, \mathrm{Cd}$, and methoxychlor cause stress effects in freshwater mussels and snails measurable by observing destabilized lysosomes of digestive gland cell stained with neutral red. Only a few species of freshwater invertebrates have been studied using neutral red retention as a gauge of toxicity, the snails Vivparus contectus [43] and Lymnaea stagnalis [44], and the bivalves, Dreissena polymorpha $[29,30]$, and Lamellidens marginalis [45]. Our use of a unionid bivalve, Elliptio complanata, and a planorbid snail, Helisoma trivolvis in the present study increases the number of freshwater invertebrate species tested, and both have a broad North American geographical distribution. Furthermore, $H$. trivolvis is more sensitive to $\mathrm{Cd}$ and methoxychlor than is $E$. complanata. For $\mathrm{Cu}$, our lowest observed effect concentration (LOEC) was $2.5 \mu \mathrm{g} / \mathrm{L}$ for both E. complanata and $H$. trivolvis over 7 and 14 days of exposure. But for $H$. trivolvis, the $\mathrm{Cd}$ and methoxychlor LOECs were 2.5 and $10 \mu \mathrm{g} / \mathrm{L}$, respectively over 7 days, whereas neither $\mathrm{Cd}$ nor methoxychlor significantly affected the percent of lysosomal destabilization in E. complanata. After 14 days exposure, the LOECs for $\mathrm{Cu}$ and $\mathrm{Cd}$ were the same for both species $(2.5 \mu \mathrm{g} / \mathrm{L})$, but the methoxychlor LOEC was 10 times lower for H. trivolvis $(1.0 \mu \mathrm{g} / \mathrm{L})$ than for $E$. complanata. It is unclear why $H$. trivolvis was more sensitive to $\mathrm{Cd}$ and methoxychlor than was $E$. complanata. Brown et al. [46], found a $\mathrm{Cu}$ toxicity difference over 7 days between marine snails and mussels. Their $\mathrm{Cu}$ LOEC for lysosomal destabilization in the limpet Patella was $6.1 \mu \mathrm{g} / \mathrm{L}$ but in the mussel Mytilus it was $68 \mu \mathrm{g} / \mathrm{L}$. They hypothesized that the difference in $\mathrm{Cu}$ sensitivity between species was possibly due to differences in $\mathrm{Cu}$ uptake via food. In our study, the food sources for $H$. trivolvis and E. complanata would likely be very similar. Both species occur in the same creek habitat often living within a few centimeters of each other. While E. complanata is a filter feeder and $H$. trivolvis consumes benthic organic material, this material is mainly settled particles. These particles could easily be re-suspended and consumed by E. complanata. A alternative explanation for the differences in toxicant sensitivity could be that $H$. trivolvis is a pulmonate snail, has no operculum, and thus cannot prevent exposure to the environment, whereas $E$. complanata is capable of completely closing its valves for varying periods of time, thus effectively reducing toxicant uptake.

In previous studies on $\mathrm{Cu}$ toxicity [43], workers exposed the snail Viviparus contectus to $\mathrm{Cu}$ concentrations from 31$100 \mu \mathrm{g} / \mathrm{L}$. Snails at all concentrations had significantly lower neutral red retention time compared to controls. Russo and co-workers $[44,47]$ reported a significant decrease in neutral red retention time in the pond snail Lymnaea stagnalis exposed to the herbicides fomesafen and atrazine, respectively. Marine mollucs have been the subject of many $\mathrm{Cu}$ toxicity studies using neutral red retention assay in destabilized lysosomes. Shepard and Bradley [48] showed a dosedependent, $\mathrm{Cu}$-induced $(20-80 \mu \mathrm{g} / \mathrm{L})$ increase in lysosomal destabilization in the mussel Mytilus edulis after only 24 hours. Ringwood et al. [13] exposed oysters to $\mathrm{Cu}$ concentrations from 2.5 to $20 \mu \mathrm{g} / \mathrm{L}$ over periods of $18 \mathrm{hrs}$, and 4,7 , and 14 days. They found lysosomal destabilization significantly increased at 7 and 14 days, but with a decrease in 
destabilized lysosomes at day 14 at $2.5 \mu \mathrm{g} / \mathrm{L}$ and $10.0 \mu \mathrm{g} / \mathrm{L}$. Our study showed an increase instead of decrease in lysosomal destabilization from 7 to 14 days at all concentrations. Nicholson [49] found that elevated $\mathrm{Cu}$ decreased neutral red retention time in the mussel Perna viridis. Matozzo et al. [16] found significant lysosomal destabilization at concentrations from $10-110 \mu \mathrm{g} / \mathrm{L}$ in the bivalve Tapes philippinarum.

There have been even fewer studies on the toxic effects of Cd using lysosomal destabilization. Matozzo et al. [16] showed that $\mathrm{Cu}$ had a stronger effect on destabilized lysosomes than $\mathrm{Cd}$ did even when the concentrations of $\mathrm{Cd}$ were two to three times higher than that of $\mathrm{Cu}$ in the marine clam Tapes philippinarum. In their study, they found high percentages of destabilized lysosomes at high $\mathrm{Cd}$ concentrations, but these were not significantly different from controls due to variance in control lysosomal destabilization. We used the same range of concentrations of $\mathrm{Cu}$ and $\mathrm{Cd}$ in our study, but the effect of $\mathrm{Cu}$ on lysosomal destabilization was evident after 7 days, whereas the effect of $\mathrm{Cd}$ became significant only after 14 days.

While no study to date has employed a neutral red lysosomal destabilization assay for effects of methoxychlor on an aquatic invertebrate, other studies on organochlorines or organophosphate pesticides have. Oysters exposed to chlordane show a negative correlation between neutral red retention time and increasing exposure [50]. Similarly, Canty et al. [51] showed that sea mussels exposed to the organophosphate Azamethiphos decreased neutral red retention time. Furthermore, while not an aquatic invertebrate, earthworms exposed to organophosphates (chlorpyrifos and diazinon) had significantly reduced neutral red retention time [37].

The cellular mechanism of lysosomal membrane destabilization has been shown to involve activation of $\mathrm{Ca}^{+2}$-dependent phospholipase $\mathrm{A}_{2}\left(\mathrm{PLA}_{2}\right)$ in marine mussel hemocytes exposed to estradiol [52] and to $\mathrm{Hg}^{+2}$ and $\mathrm{Cu}^{+2}$ [53]. $\mathrm{Hu}$ et al. [54] have shown that $\mathrm{PLA}_{2}$ induces the production of the lipid metabolite lysophosphatidylcholine (lysoPC) in rat liver cells. LysoPC changes the permeability of lysosomal membranes to $\mathrm{K}^{+}$and $\mathrm{H}^{+}$causing the entry of $\mathrm{K}^{+}$into the lysosome via a $\mathrm{K}^{+} / \mathrm{H}^{+}$enchanger. Ultimately, the lysosome disintegrates from osmotic shock. How PLA 2 regulates lysosomal membrane destabilization in mussel hemocytes or other molluscan cells remains unknown.

Many recent toxicity studies using neutral red retention assays in lysosomes of molluscs have utilized hemocytes $[29,30,33,44,47]$. We measured lysosomal destabilization in molluscan digestive gland cells. Such cells have been used in neutral red retention assays previously in marine molluses [13, 34]. Moreover, Lowe et al. [55] found no difference in neutral red retention time between hemocytes and digestive gland cells marine mussels exposed to fluorathene.

Neutral red retention assay has been used as a reliable indicator of stress in aquatic organisms. Our study is one of the few that addresses stress induced by heavy metals and pesticides as measured by this assay in freshwater invertebrates. It should be noted that environmental conditions such as aerial exposure [56], or high temperature and high salinity
[49] can induce lysosomal destabilization. The two species examined in our study undergo periods of seasonal environmental fluctuation. Elliptio complanata forms dense beds in shallow sediments near the air-water interface in small streams. During summer, water levels typically drop by several feet, leaving mussels exposed to air where they are subject to desiccation and predation. During summer, mussels are often seen migrating slowly towards the receding water line. Helisoma trivolvis lives in a similar habitat to $E$. complanata, except that they are found in large numbers on rocks that are frequently exposed to air during the summer. Thus, both species undergo seasonal environmental stress. Despite this, our field control animals had low percentages of lysosomal destabilization $(<20 \%)$.

Freshwater molluses are excellent sentinel species and the two test organisms are common and widespread throughout much of North America. Our study supports the use of neutral red retention assay as a reliable indicator of environmental stress in freshwater invertebrates.

\section{CONFLICT OF INTEREST}

None declared.

\section{ACKNOWLEDGEMENTS}

We thank the Biology Department and Office of the Provost of Gettysburg College for funding.

\section{REFERENCES}

[1] Pesando D, Robert S, Huitorel P, et al. Effects of methoxychlor, dieldrin and lindane on sea urchin fertilization and early development. Aquat Toxicol 2004; 66: 225-39.

[2] Dodson SI. Introduction to Limnology. New York: NY McGrawHill 2005; p. 400.

[3] Gagneten AM, Gervasio S, Paggi JC. Heavy metal pollution and eutrophication in the lower Salado River basin (Argentina). Water Air Soil Pollut 2007; 178: 335-49.

[4] Farris JL, Van Hassel JH. Freshwater Bivalve Ecotoxicology. Boca Raton, FL: CRC Press 2007; p. 375.

[5] Naimo TJ. A review of the effects of heavy metals on freshwater mussels. Ecotoxicology 1995; 4: 341-62.

[6] de Oliviera EC, Lopes RM, Paumgartten FJR. Comparative study on the susceptibility of freshwater species to copper-based pesticides. Chemosphere 2004; 56: 369-74.

[7] Pena SC, Pocsido GN. Influence of copper on the feeding rate, growth and reproduction of the golden apple snail, Pomacea canaliculata Lamarck. Bull Environ Contam Toxicol 2007; 79: 605-8.

[8] Vinodhini R, Narayanan M. Bioaccumulation of heavy metals in organs of fresh water fish Cyprinus carpio (Common carp). Int $\mathrm{J}$ Environ Sci Tech 2008; 5: 179-83.

[9] Reddy NM, Rao PV. Copper toxicity to the fresh water snail, Lymnaea luteola. Bull Environ Contam Toxicol 1987; 39: 50-5.

[10] Byrne RA, O'Halloran J. The role of bivalve mollusks as tools in estuarine sediment toxicity testing: a review. Hydrobiologia 2001; 465: 209-17.

[11] Pietrock M, Meinelt T, Marcogliese DJ. Effects of cadmium exposure on embryogenesis of Stagnicola elodes (Mollusca, Gastropoda): potential consequences for parasite transmission. Arch Environ Contam Toxicol 2008; 55(1): 43-8.

[12] Hoang TC, Pryor RL, Rand GM, Frakes RA. Bioaccumulation and toxicity of copper in outdoor freshwater microcosms. Ecotoxicol Environ Saf 2011; 74(4): 1011-20.

[13] Ringwood AH, Conners DE, Hoguet J. Effects of natural and anthropogenic stressors on lysosomal destabilization in oysters Crassostrea virginica. Mar Ecol Prog Ser 1998; 166:163-71. 
[14] Ringwood AH, Sokolova IM, Johnson C. Tissue-specific accumulation of cadmium in subcellular compartments of eastern oysters Crassostrea virginica Gmelin (Bivalvia: Ostreidae). Aquat Toxicol 2005; 74: 218-28.

[15] Viarengo A, Marro A, Marchi B, Burlando B. Single and combined effects of heavy metals and hormones on lysosomes of haemolymph cells from the mussel Mytilus galloprovincialis. Mar Biol 2000; 137: 907-12.

[16] Matozzo V, Ballarin L, Pampanin DM, Marin MG. Effects of copper and cadmium exposure on functional responses of hemocytes in the clam, Tapes philippinarum. Arch Environ Contam Toxicol 2001; 41: 163-70.

[17] Hoarau P, Garello G, Gnassia-Barelli M, Roméo M, Girard, JP. Effect of three xenobiotic compounds on Glutathione S-Transferase in the clam Ruditapes decussatus. Aquat Toxicol 2004; 68: 87-94.

[18] Bedford JW, Roelofs EW, Zabik MJ. The freshwater mussel as a biological monitor of pesticide concentrations in a lotic environment. Limnol Oceanogr 1968; 13: 118-26.

[19] Leong KH, Tan LL, Mustafa AM. Contamination levels of selected organochlorine and organophosphate pesticides in the Selangor River, Malaysia between 2002 and 2003. Chemosphere 2007; 66(6): 1153-9.

[20] Kim K-B, Kim SH, Um SY, et al. Metabolomics approach to risk assessment: Methoxychlor exposure in rats. J Toxicol Environ Health 2009; 72(21-22): 1352-68.

[21] Schuh RA, Richardson JR, Gupta RK, Flaws JA, Fiskum G. Effects of the organochlorine pesticide methoxychlor on dopamine metabolites and transporters in the mouse brain. Neurotoxicology 2009; 30: 274-80.

[22] Relyea RA. The impact of insecticides and herbicides on the biodiversity and productivity of aquatic communities. Ecol Appl 2005; 15(2): 618-27.

[23] Murray KE, Thomas SM, Bodour AA. Prioritizing research for trace pollutants and emerging contaminants in the freshwater environment. Environ Pollut 2010; 158: 3462-71.

[24] Ringwood AH, Levi-Polyachenko N, Carroll DL. Fullerene exposures with oysters: embryonic, adult, and cellular responses. Environ Sci Technol 2009; 43: 7136-41.

[25] Dailianis S, Domouhtsidou GP, Raftopoulou E, Kaloyianni M, Dimitriadis VK. Evaluation of neutral red retention assay, micronucleus test, acetylcholinesterase activity and a signal transduction molecule (cAMP) in tissues of Mytilus galloprovincialis (L.) in pollution monitoring. Mar Environ Res 2003; 56: 443-70.

[26] Mamaca E, Bechmann RK, Torgrimsen S, et al. The neutral red lysosomal retention assay and Comet assay on haemolymph cells from mussels (Mytilus edulis) and fish (Symphodus melops) exposed to styrene. Aquat Toxicol 2005; 75: 191-201.

[27] Moore MN, Allen JI, McVeigh A. Environmental prognostics: An integrated model supporting lysosomal stress response as predictive biomarkers of animal health status. Mar Environ Res 2006; 61: 278-304

[28] Song L, Li X, Clarke S, Wang T, Bott K. The application of neutral red retention assay to evaluate the differences in stress responses to sexual maturation and spawning between different sizes of Pacific oyster, Crassostrea gigas (Thunberg). J Shellfish Res 2007; 26: 493-9.

[29] Binelli A, Cogni D, Parolini M, Riva C, Provini A. In vivo experiments for the evaluation of genotoxic and cytotoxic effects of Triclosan in Zebra mussel hemocytes. Aquat Toxicol 2009; 91: 238-44.

[30] Binelli A, Cogni D, Parolini M, Riva C, Provini A. Cytotoxic and genotoxic effects of in vitro exposure to Triclosan and Trimethoprim on zebra mussel (Dreissena polymorpha) hemocytes. Comp Biochem Physiol C 2009; 150: 50-6.

[31] Coughlan BM, Moroney GA, van Pelt FNAM, O’Brien NM, Davenport J, O'Halloran J. The effects of salinity on the Manila clam (Ruditapes philippinarum) using the neutral red retention assay with adapted physiological saline solutions. Mar Pollut Bull 2009; 58: 1680-4.

[32] Parolini M, Binelli A, Cogni D, Riva C, Provini A. An in vitro biomarker approach for the evaluation of the ecotoxicity of nonsteroidal anti-inflammatory drugs (NSAIDs). Toxicol In Vitro 2009; 23: 935-42.

[33] Parolini M, Binelli A, Cogni D, Provini A. Multi-biomarker approach for the evaluation of the cyto-genotoxicity of paracetamol on the zebra mussel (Dreissena polymorpha). Chemosphere 2010; 79: 489-98.

[34] Lowe DM, Pipe PK. Contaminant induced lysosomal membrane damage in marine mussel digestive cells: an in vitro study. Aquat Toxicol 1994; 30: 357-65.

[35] Moore MN. Cellular responses to pollutants. Mar Pollut Bull 1985; 16: 134-9.

[36] Keppler CJ, Ringwood AH, Hoguet J, Smith K, Lewitus AJ. Sublethal effects of the toxic alga Heterosigma akashiwo on the southeastern oyster (Crassostrea virginica). Harmful Algae 2005; 4: 275-85.

[37] Booth LH, Heppelthwaite VJ, Webster R, O'Halloran K. Lysosomal neutral red retention time as a biomarker of organophosphate exposure in the earthworm Aporrectodea calignosa: laboratory and semi-field experiments. Biomarkers 2001; 6: 77-82.

[38] Johnston BR, Halton DW, Moore MN. Bucephaloides gracilescens: A quantitative study of the lysosomal cellular stress response induced by the sporocyst and developing cercariae within the white furrow shell, Abra alba. Parasitol Res 1982; 67: 31-6.

[39] Stefanoni MF, Abessa DMS. Lysosomal membrane stability of the brown mussel Perna perna (Linneus) (Mollusca, Bivalvia) exposed to the anionic surfactant linear alkylbenzene sulphonate (LAS). Pan-Amer J Aquat Sci 2008; 3: 6-9.

[40] Otludil B, Cengiz EI, Yildirim MZ, Unver O, Unlu E. The effects of endosulfan on the great ramshorn snail Planorbarius corneus (Gastropoda, Pulmonata): a histopathological study. Chemosphere 2004; 56: 707-16.

[41] Won S-J, Novillo A, Cstodia N, et al. The freshwater mussel (Elliptio complanata) as a sentinel species: vitellogenin and steroid receptors. Integr Comp Biol 2005; 45: 72-80.

[42] Versonnen BJ, Roose P, Monteyne EM, Janssen CR. Estrogenic and toxic effects of methoxychlor on zebrafish (Danio rerio). Environ Toxicol Chem 2004; 23: 2194-201.

[43] Svendsen C, Weeks JM. The use of a lysosome assay for the rapid assessment of cellular stress from copper to the freshwater snail Viviparus contectus (Millet). Mar Pollut Bull 1995; 31: 139-42.

[44] Russo J, Orfila-Lefeuvre L, Lagadic L. Hemocyte-specific responses to the peroxidizing herbicide fomesafen in the pond snail Lymnaea stagnalis (Gastropoda, Pulmonata). Environ Pollut 2007; 146: 420-7.

[45] Chakraborty S, Ray S. Nuclear morphology and lysosomal stability of molluskan hemocytes as possible biomarkers of arsenic toxicity. Clean Soil Air Water 2009; 37(10): 769-75.

[46] Brown RJ, Galloway TS, Lowe D, et al. Differential sensitivity of three marine invertebrates to copper assessed using multiple biomarkers. Aquat Toxicol 2004; 66: 267-78.

[47] Russo J, Madec L, Brehelin H. Haemocyte lysosomal fragility facing an environmental reality: a toxicological perspective with atrazine and Lymnaea stagnalis (Gastropoda, Pulmonata) as a test case. Ecotoxicol Environ Saf 2009; 72: 1719-26.

[48] Shepard JL, Bradley BP. Protein expression signatures and lysosomal stability in Mytilus edulis exposed to graded copper concentrations. Mar Environ Res 2000; 50: 457-63.

[49] Nicholson S. Ecocytological and toxicological responses to copper in Perna viridis (L.) (Bivalvia: Mytilidae) haemocyte lysosomal membranes. Chemosphere 2001; 45: 399-407.

[50] Gold-Bouchot G, Zapata-Pérez O, Ceja-Moreno V, et al. Biological effects of environmental pollutants in American Oyster, Crassostrea virginica: a field study in Laguna de Terminos, Mexico. Int J Environ Health 2007; 1: 171-84.

[51] Canty MN, Hagger JA, Moore RT, Cooper L, Galloway TS. Sublethal impact of short term exposure to the organophosphate pesticide azamethiphos in the marine mollusc Mytilus edulis. Mar Pollut Bull 2007; 54: 396-402.

[52] Burlando B, Marchi B, Panfoli I, Viarengo A. Essential role of $\mathrm{Ca}^{2+}$-dependent phospholipase A2 in estradiol-induced lysosome activation. Am J Physiol Cell Physiol 2002; 283: 1461-8.

[53] Marchi B, Burlando B, Moore MN, Viarengo A. Mercury- and copper-induced lysosomal membrane destabilization depends on $\left[\mathrm{Ca}^{2+}\right]_{\mathrm{I}}$ dependent phospholipase A2 activation. Aquat Toxicol 2004; 66: 197-204.

[54] Hu J-S, Li Y-B, Wang J-W, Sun L, Zhang G-J. Mechanism of lysophosphatidylcholine-induced lysosome destabilization. J Membr Biol 2007; 215: 27-35. 
[55] Lowe DM, Soverchia C, Moore MN. Lysosomal membrane responses in the blood and digestive cells of mussels experimentally exposed to fluoranthene. Aquat Toxicol 1995; 33: 105-12.
[56] Zhang Z, Li X, Vandepeer M, Zhao W. Effects of water temperature and air exposure on the lysosomal membrane stability of hemocytes in Pacific oysters, Crassostrea gigas (Thunberg). Aquaculture 2006; 256: 502-9.

Received: February 15, 2012

Revised: March 25, 2012

Accepted: April 4, 2012

(C) Molnar and Fong; Licensee Bentham Open.

This is an open access article licensed under the terms of the Creative Commons Attribution Non-Commercial License (http://creativecommons.org/licenses/bync/3.0/), which permits unrestricted, non-commercial use, distribution and reproduction in any medium, provided the work is properly cited. 